\title{
O HISTÓRICO E O FANTÁSTICO EM O MEZ DA GRIPPE
}

\author{
THE HISTORICAL AND THE FANTASY LITERATURE \\ IN O MEZ DA GRIPPE
}

Naira de Ameida Nascimento ${ }^{1}$

Rogério Caetano de Almeida ${ }^{2}$

Resumo: $O$ romance histórico e a literatura fantástica traçaram caminhos excludentes durante a segunda fase da modernidade, em pleno século XIX. Enquanto a primeira guiava-se pela margem segura dos documentos, o gênero fantástico denunciava a precária hegemonia daquela crença e apontava para a instabilidade do "real". 0 romance latino-americano, denominado romance do boom, favoreceu, entre outras experiências ficcionais, a aproximaçăo do histórico e do fantástico, ao confrontar um discurso centrado na voz do colonizador e cego às culturas e às tradiçôes das sociedades colonizadas. O mez da grippe, de autoria de Valêncio Xavier, compartilha esse estatuto ao lidar com o registro documental e concomitantemente estabelecer uma atmosfera fantasmagórica, mas, diferentemente do primeiro, ele constrói o insólito por meio de uma apresentaçáo saturada dos registros documentais e pelas dissensóes criadas entre eles.

Palavras-chave: Fantástico. Ficçăo histórica. O mez da grippe. Valêncio Xavier.

Abstract: During the second turn of Modernity, in the nineteenth century, the historical novel and fantasy fantastic literature have both outlined sundry and excluding pathways. While the former was guided by the safe orientation of records, the latter denounced the precarious hegemony of a warning and warned about belief in the instability of "reality" as a category. Latin American novels, during its booming period, favored, amongst other fictional experiences, the convergence of history and the fantastic fantasy, since it showed a colonizer-driven discourse, blind either to cultures or to traditions of colonized societies. O Mez da Grippe, by Valêncio Xavier, shares this kind of ideal, when coping with documented record and its corresponding creation of playfulness, since, unlike other works, it stresses a weird ambience by fiercely presenting documented records and by creating dissent.

Keywords: Fantasy literature. Historical fiction. O mez da grippe. Valêncio Xavier.

1 Professora Adjunta de Literaturas de Língua Portuguesa da UTFPR. Doutora em Estudos Literários pela UFPR. E-mail: naira.alm@gmail.com.

2 Professor Adjunto de Literaturas de Língua Portuguesa da UTFPR. Doutor em Estudos Comparados pela USP.E-mail: rogalmeida01@hotmail.com. 
Data de 1949, aproximadamente, a incursăo nos domínios do insólito de um sub-gênero narrativo até entấo insuspeito a essas latitudes. Referimo-nos ao romance histórico e, mais curioso ainda, é que o fato se deu pelas măos de conhecido teórico, ligado ao real maravilhoso, o escritor Alejo Carpentier, com a publicaçăo de $O$ reino desse mundo.

Seguramente, Carpentier năo foi o único escritor a cruzar tais barreiras narrativas, normalmente delimitadas e estranhas uma a outra. Foi, contudo, essa a versâo construída por Seymour Menton ao cunhar o termo Novo Romance Histórico para identificar uma mudança de paradigma nos rumos do subgênero narrativo, estudado e descrito anteriormente pelo crítico marxista Gyorgy Lúkacs, em seu clássico 0 Romance Histórico (1955).

É de se destacar que a ocorrência que segue ao do romance de 1949 só se dá em 1962, com O século das luzes, novamente sob a responsabilidade do escritor cubano. A partir de entâo, uma longa listagem de títulos se verifica, cobrindo os países mais representativos da América Latina, como Colômbia, Argentina, México, Chile, Equador, Venezuela, Peru, Brasil, Cuba, Uruguai, Paraguai, Nicarágua, Guatemala, encerrando-se em 1992, data do término da pesquisa realizada por Menton.

A questâo que se colocava entăo era: que características tornavam aquela produçâo, com uma localizaçăo privilegiada sobretudo na América Latina, tăo distinta da outra, iniciada mais de cem anos antes com Walter Scott, nos planaltos escoceses? É verdade que muitos dos critérios elencados por Menton dizem respeito, năo propriamente à tipologia histórica, mas se devem, em grande parte, às transformaçóes sofridas pelo gênero romanesco, tais como a metaficçấo, a intertextualidade e a recorrência a procedimentos descritos por Bakhtin, como é o caso do dialogismo, da carnavalizaçấo, da heteroglosia. Poderíamos até mesmo concluir que o peso dessas ocorrências constitui marca relevante da produçâo contemporânea, conforme já anotado por Marilene Weinhardt (2006, p. 190).

Já outros quesitos, como o protagonismo de personagens históricos, antes tomados de forma secundária, a distorçấo consciente da história por meio de exageros, anacronismos e omissóes, e a submissăo do enredo a certas ideias filosóficas, de acordo com um modelo experimentado em Borges, nos colocam no encalço de uma composiçấo que rompia com os paradigmas do subgênero. Segundo Menton, tais ideias filosóficas, inspiradas no escritor argentino, apontam para a impossibilidade de se conhecer a verdade histórica ou a realidade, além de sinalizar para o caráter cíclico e, paradoxalmente, imprevisível da história (MENTON, 1993, p. 42).

Isto porque o que parecia apartar sobremaneira a ficçăo insólita da produçăo histórica era justamente o pacto referencial. Enquanto o romance histórico primava pelo respeito às balizas documentais, tentando se dirigir por ele, ao fantástico impunha-se diluir a certeza das açôes explicadas cientificamente. A "realidade", entendida ainda como algo verificável de forma universalista, construía os modelos de leitores, ou leitores implícitos conforme Umberto Eco, demandados por cada subgênero ficcional. 0 rigor às fontes, a segurança de se ler o passado, ainda que estimulada a recorrência à imaginaçâo criadora na composiçâo de personagens, enredos e situaçôes, opunha-se ao terror gerado por narrativa que desafiavam os princípios de um mundo fundado entâo pelo empirismo. 
Herdeiras do pacto referencial, literatura fantástica e romance histórico sâo por isso mesmo filhos da Modernidade, um ambiente que promete aventuras, mas que também aterroriza, pelo medo da perda, os homens do século XIX (BERMAN, 1986, p. 15). Segundo o teórico da Modernidade, em relaçăo ao novo espaço social:

Trata-se de uma paisagem de engenhos a vapor, fábricas automatizadas, ferrovias, amplas novas zonas industriais; prolíficas cidades que cresceram do dia para a noite, quase sempre com aterradoras consequências para o ser humano; jornais diários, telégrafos, telefones e outros instrumentos de media, que se comunicam em escala cada vez maior; Estados nacionais cada vez mais fortes e conglomerados multinacionais de capital; movimentos sociais de massa, que lutam contra essas modernizaçóes de cima para baixo, contando só com seus próprios meios de modernizaçấo de baixo para cima; um mercado mundial que a tudo abarca, em crescente expansăo, capaz de um estarrecedor desperdício e devastaçăo, capaz de tudo exceto solidez e estabilidade. (BERMAN, 1986, p. 18).

Descobertas científicas importantes, modernizaçăo técnica acelerada, explosăo demográfica e intensa industrializaçăo da produçăo (BERMAN, 1986, p. 16), săo os fatores que, combinados, concorreram para uma nova sensibilidade em que as tentativas de apreensăo através de ferramentas de mensuraçăo, pensadas como universais, se fazia visível. Tempo e espaço participaram ativamente desse processo.

Cidades organizadas, espaços racionalizados, como previu a política de Napoleâo III, continuada pelo Barăo de Hausmann, na Paris de meados do séc. XIX, enquanto com Tony Garnier aprendemos sobre a setorizaçâo do corpo/cidade: trabalho, habitaçấo, lazer e tráfego: "A zona industrial encontra-se isolada por um cinturăo verde; os bairros cumprem um papel exclusivamente residencial; na zona central concentram-se os serviços públicos; um local específico é reservado ao lazer (piscinas, quadras etc.)." (ORTIZ, 1998, p. 210). Também, além dos muros da cidade, a percepçâo sobre o espaço muda radicalmente: "A diligência e o cavalo os havia habituado [aos homens] a contemplar de perto a natureza envolvente. $O$ trem quebra esta percepçăo de continuidade, os espaços locais tornam-se elementos descontínuos, pontilhados ao longo da viagem." (ORTIZ, 1998, p. 222).

Quanto ao tempo, imprime-se o ritmo de Cronos. "O ‘preço do tempo' altera o passo das pessoas, elas transitam mais rápido do que 'antigamente"' (ORTIZ, 1998, p. 224). 0 tempo da indústria, da produçâo requer disciplina e regularidade. Novamente os caminhos do trem sujeitam a sociedade a uma sincronia antes desnecessária; os relógios ajustam-se para dar corpo à civilizaçấo.

A modernidade constitui um sistema no qual as partes estăo interligadas entre si.
Para que o fluxo no seu interior se faça de maneira ordenada, a regência do tempo
é essencial. Os movimentos devem ser orquestrados para se evitar situaçáo caótica.
Os atrasos, as rupturas, năo sáo portanto simples ressonâncias do passado, mas um
obstáculo para o andamento do todo. Tempo funçáo, sempre avaliado em referência
à realizaçấo de uma açáo específica (produçáo de um objeto, deslocamento na cidade
etc.). (ORTIZ, 1998, p. 242).

Sintonizado ao movimento que impulsiona a vivência moderna, o romance histórico pactua com a euforia da marcha da história, encontrando aí sua própria razăo de ser, de acordo com seu teórico mais eminente. A retrataçâo do passado năo se justifica 
pela fuga ao presente, mas, ao contrário, serve como estímulo para o engajamento do homem no seu tempo.

Se a essa experiência vem unir-se o reconhecimento de que tais revoluçōes ocorrem no mundo inteiro, fortalece-se extraordinariamente o sentimento de que existe uma história, de que essa história é um processo ininterrupto de mudanças e, por fim, de que ela interfere diretamente na vida de cada indivíduo. (LUKÁCS, 2011, p. 38).

Ou ainda, em relaçăo ao paradigma por excelência do romance histórico:

É raro que Walter Scott fale do presente. Em seus romances, náo aborda as questōes sociais do presente inglês, como o acirramento incipiente e incisivo da luta de classes entre a burguesia e o proletariado. Na medida em que ele pode responder por si mesmo a essas questóes, ele o faz pelo viés da figuraçáo ficcional das etapas mais importantes da história inteira da Inglaterra. (LUKÁCS, 2011, p. 49).

O romance fantástico, por sua vez, parece tecer o diálogo com a Modernidade sob o signo da suspeiçâo, náo mais a partir da visada otimista, dominante naquela ficçâo histórica. Insinuar a ambiguidade que prevalece nas situaçôes narradas lança năo apenas o mistério, mas esconjura, a seu modo, o espírito do homem científico. A dúvida e a impressăo de desconforto causadas no leitor permanecem e tornam-se os elementos vitais no que se convencionou chamar de modo fantástico, modo este que, conforme Remo Ceserani (2006, p. 12), permeia gêneros e subgêneros diversos. Ele desconfia do "real". "O fantástico é a hesitaçâo experimentada por um ser que só conhece as leis naturais, face a um acontecimento aparentemente sobrenatural." (TODOROV, 1975, p. 31).

Enquanto o romance histórico endossa o modelo de leitura da história proposto pelo séc. XIX, a literatura fantástica rebela-se em relaçăo ao cientificismo. Nâo deixa de ser curioso, contudo, que grande parte dos autores realistas tenha assinado narrativas mais curtas que incursionam pelo fantástico. Vale lembrar também que Edgar Allan Poe protagonizou dois gêneros que se dividiam na querela cientificista: o fantástico e o policial. Juntamente ao histórico, teríamos um florescimento literário que contempla antes de tudo o pacto referencial, ou o real, em linhas simplistas, com o aparato do discurso científico, hegemônico nessa altura.

É Ronaldo Lima Lins quem melhor sintetiza o lugar do fantástico na era da Modernidade:

Assim, por um lado temos uma realidade pragmática, inexoravelmente em expansâo, feita de cálculo e objetividade, erguida sobre a eficiência e o progresso, umarealidade queacentua aintensidade dacrise comose dependesse desta para permanecer e desenvolver-se. Por outro lado, da representaçăo da realidade o retrato que se desenha fala sobre a angústia, sobre a fragmentaçăo e sobre o desencanto, em pinceladas que se banham no imaginário, no absurdo e no fantástico, regiōes onde năo há limites marcados, nem ordem, nem relógio. O artista europeu brinca com as palavras, preso a regras de instituiçóes que já o preveem, amparado pelo seguro social, como um louco entre a lucidez e o delírio, que percebe pouca ou nenhuma possibilidade de transformar o mundo. Sua inquietaçâo se reflete na exacerbaçăo do espírito lúdico, elevado à categoria máxima da existência, para o qual a forma é a mensagem, numa homologia evidente à prática quotidiana do quadro social. É o caso em que o fantástico, resposta literária ao mito da Razăo, passa pelo absurdo e veste, 
enfim, a máscara da horrível alma do outro mundo da vida moderna, que é a coisa. (LINS, 1990, p. 44).

Essa dualidade, presente na oposiçăo entre o histórico e o fantástico, sofre modificaçấo substancial em meados do século XX. A produçấo que se tornou conhecida no boom latino-americano, pelo impacto que assistiu na prosa literária, impôs uma nova discussăo nos domínios teóricos. "Real maravilhoso" e "realismo mágico" tornaram-se expressōes que buscavam definir o estatuto do insólito praticado na América Latina. Em que pese a herança surrealista no processo, o certo é que a reivindicaçăo partia de uma condiçăo existencialista, possibilitada pelas latitudes, por sua herança cultural e por um histórico comum de luta contra o colonizador.

Se a novidade gerou polêmicas relevantes no âmbito do insólito, o que dizer dos desdobramentos no campo da ficçăo histórica? De baluarte do discurso racional, fundado na segurança documental, o romance de Alejo Carpentier implodia as regras do subgênero em seu elemento mais basilar. Em $O$ reino desse mundo, ao evocar os antecedentes da independência do Haiti, no início do século XVIII, o narrador năo apenas se coloca claramente ao lado da perspectiva do escravo, mas também a narrativa dá forma aos sonhos mágicos dos personagens oprimidos, rompendo com a lógica cartesiana do romance histórico tradicional. Inaugura-se, assim, uma nova linhagem do romance histórico, aliando os elementos do insólito, antes expurgados pelo gênero, ao documental.

\section{O MEZ DA GRIPPE}

Lido enquanto ficçáo histórica por tematizar a epidemia da gripe espanhola em Curitiba no ano de 1918, 0 Mez da grippe levanta até hoje questóes acerca de pertencimentos, considerando a sua radicalidade enquanto experiência literária. Transcendendo as diferenças entre os gêneros textuais utilizados, o livro de Valêncio Xavier se constitui no uso de diferentes linguagens, às quais se afirmam, se negam e se renegam; constroem uma tese, uma síntese e uma anti-síntese; coadunam-se na diferença e negam-se sem se refutar completamente na discussăo do tema geral da obra que é o período em que a capital paranaense foi assolada pela gripe espanhola. Tal construçăo se viabiliza através do uso indiscriminado de categorias ligadas à sátira - a paródia, o pastiche e a ironia - concatenadas com o que se convencionou chamar de intermidialidade. $O$ experimentalismo é inclusive assumido pelo autor em entrevista:

Imaginava que o Mez da Grippe ia fazer certo sucesso entre meu público costumeiro, mais de ambiente universitário ou especializado. Mas pegou também o público geral, que se diverte e năo se chateia com minhas histórias. Há muitos nesse Brasil afora, considerados malditos, que fazem uma literatura experimental sem querer cagar regras, ou meter sapiência, ideologias e mágoas em seus textos, ou imitando esse e aquele - escrevem só pelo prazer de escrever. (KUBOTA, 2008).

O sofisticado jogo entre diferentes linguagens (verbal e năo-verbal) e diferentes gêneros textuais fez com que sua obra chamasse a atençâo de críticos como Boris Schnaidermann, Décio Pignatari e Flora Sussekind que, além de reconhecerem o trabalho inventivo do artista conhecido até entăo apenas regionalmente, apoiaram a 
reediçăo de 0 mez da grippe pela Companhia das Letras em 1998. O livro, publicado inicialmente em 1981 pela Fundaçáo Cultura de Curitiba, trata, nesse amálgama de linguagens, do surto do vírus Influenza $\mathrm{H} 1 \mathrm{N1}$, mais popularmente conhecido à época como gripe espanhola, que acometeu a cidade de Curitiba entre outubro e dezembro de 1918. Se em geral os textos sobre esta obra incidem sobre uma crítica aos jornais e ao discurso oficial, aqui verificaremos como essas diferentes linguagens e diferentes gêneros textuais se entrecruzam ao longo do texto construindo uma atmosfera fantasmagórica. Esse efeito é particularmente curioso, visto que a composiçăo do texto se dá quase que exclusivamente por registros documentais, tais como notícias de jornais, anúncios publicitários, depoimentos, relatórios médicos, fotos. Ou seja, cabe ao recorte e à acomodaçấo dos registros díspares, porém factuais, uma impressáo de irrealidade que impera no romance.

A primeira imagem que escolhemos para demonstrar como há um esforço para registrar os paradoxos daquela sociedade à época por meio do fantástico, ou do insólito, a depender da perspectiva adotada para interpretar tal figura, é a imagem que aparece na contracapa do livro organizado em 1999 e figura como capa da $1^{\text {a }}$ ediçáo:

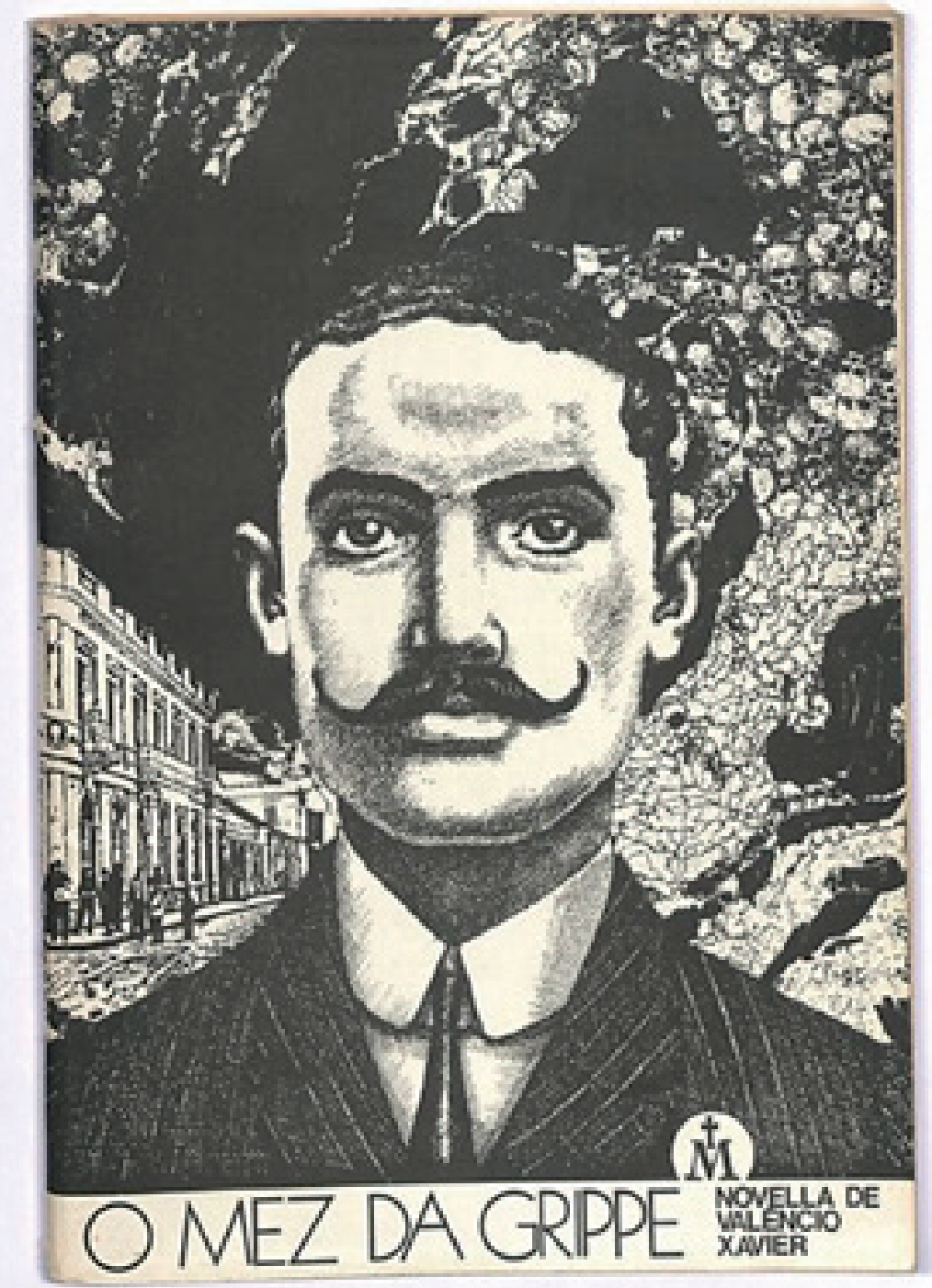


A imagem, desenvolvida pelo próprio Valêncio Xavier, carrega uma plurissignificaçăo vinculada à morte e ao enredo do livro. Apesar de na simbologia de língua portuguesa a morte ser identificada como uma figura feminina, em geral, ela se identifica também com o gênero masculino. Seu ar circunspecto com o bigode năo nos indica muita coisa, mas a ocupaçấo do espaço central sugere que há alguma relaçăo desse homem com terno de risca de giz com as mortes ocorridas na cidade: do lado esquerdo, os casaróes que, em alguns casos, resistiram à especulaçấo imobiliária e sobrevivem até hoje nas avenidas centrais da cidade săo circundados por pessoas e por paralelepípedos que, quando do lado direito da imagem, desaparecem e dăo lugar a traços que, sem um limite muito claro, transformam-se em caveiras. Estas formam uma espécie de pinça que engolfam o homem e a cidade, afinal todo o restante do céu está enegrecido. Também chama a atençăo a lapela com um símbolo que parece representar uma empresa funerária, mas nunca é aproximada do anúncio de uma dessas empresas ao longo de todo o livro. Tal imagem, um crucifixo com a letra "m" abaixo, aparece em outras ocasiōes do livro anunciando a morte da populaçăo e duas chamadas para missas em homenagem aos mortos, além de encerrar o livro. Tudo se acaba quando o homem e sua lapela aparecem ao longo da narrativa.

Apesar de a morte ser um signo ambivalente, em $O$ mez da grippe, ela ganha apenas a acepçấo de "aspecto perecível e destrutível da existência" (CHEVALIER, 2001, p. 621). O homem, representaçâo da morte, aparece em mais três imagens ao longo da narrativa. A primeira apariçâo ocorre na segunda página do livro; na primeira página, aparece o calendário de outubro de 1918 e, abaixo, a frase "alguma coisa". A ocorrência de "alguma coisa" na obra se manifesta justamente a partir da segunda página.

Num processo de colagem, há a informaçăo de que o presidente norte americano W. Wilson "nâo trata com um governo que continua a cometer toda a sorte de crimes" (XAVIER, 1998, p. 13). Independente de sabermos se essa informaçáo está relacionada à interferência americana na Revoluçăo Mexicana ou à entrada dos EUA na Primeira Guerra Mundial, pelo fato de nâo estar datada, esta, através do recorrente uso do pastiche, contribui para estender o sentido das informaçôes coladas abaixo através de noticiários que o próprio Valêncio Xavier colou e bricolou ao longo de todo o texto, sejam elas criadas por ele ou retiradas de anúncios da época. As informaçōes abaixo dizem respeito à chegada da gripe a Curitiba. Antes de citá-las, mencionamos um esforço do texto em ser permeado constantemente pela ironia. De tal maneira, o pastiche realizado pelo autor no uso do texto original muda de sentido quando colocado em contato com outros textos. Nâo seria a frase sobre o presidente Wilson a destilaçấo de uma ironia que critica o estado por năo adotar medidas profiláticas à época? É desta forma que o romance histórico é permeado pelo insólito e pelo fantástico: enquanto o estado nâo toma as atitudes necessárias para evitar um problema epidemiológico na regiâo, há um homem-morte que caminha pelo espaço citadino. Há culpados na disseminaçâo da gripe? Enquanto o mundo se esfacela na guerra de trincheiras, Curitiba vive uma guerra outra - a disseminaçăo e a tentativa de controle da gripe espanhola.

Neste sentido, o homem-morte é também uma metonímia e/ou uma personificaçăo da gripe, mas pode ser um caminhante qualquer que resolveu desafiar o controle da doença circulando pelo espaço público. O texto náo se fecha em uma única interpretaçăo, mas sugere que o homem-morte circulou de maneira insistente por Curitiba por 
descuido dos agentes responsáveis. Na mesma página do texto, uma colagem de um texto do responsável pelo diretor do serviço sanitário, Trajano Reis:

Em Paranaguá, n'aquella epocha, ia effectuar-se o casamento de uma filha do syrio Barbosa. Do Rio de Janeiro vieram assistir ás bodas alguns syrios, que estavam com o mal incubado.

De Antonina e Morretes seguiram para aquella cidade, com o mesmo fim dos do Rio, alguns patricios do Sr. Barbosa. Folgaram juntos e cada um dos residentes em Antonina e Morretes trouxe comsigo o gérmen do mal, que se disseminou com rapidez entre as populaçôes das referidas cidades. Em Paranaguá, por sua vez, os hospedes fluminenses năo só padeceram da molestia, como também a transmitiram aos patricios e á populaçăo. (XAVIER, 1998, p. 13).

A explicaçâo científica dada pela autoridade científica, corroborando uma perspectiva que possibilita compreender a obra com indícios muito fortes de um romance histórico, é desconstruída na parte final da página, que possui a presença do homem sorumbático já referido anteriormente e, ao lado, apresenta o seguinte poema:

Um homem eu caminho sozinho

nesta cidade sem gente

as gentes estăo nas casas

a grippe (XAVIER, 1998, p. 13)

Este poema sugere que o homem é simplesmente um indivíduo que circula pelas ruas. Através da fragmentaçăo do discurso, construída de muitas formas, mas mais intensamente provocativa na presença desse homem, a obra se abre para múltiplas interpretaçôes, impossibilitando a conclusăo de que houve efetivamente um erro das autoridades sanitárias. No primeiro verso do poema, é notória uma estratégia discursiva de identificar o eu no outro que se amplia quando isolamos as pessoas do discurso sem utilizar a coletividade pressuposta pelo substantivo "gente": "Um homem eu caminho sozinho [a grippe]." O poema contribui para complementar a interpretaçăo que se faz da imagem do homem - ele é a morte, a gripe e um indivíduo que circula sozinho pela cidade à mercê da gripe (ele mesmo), enquanto as pessoas se escondem em suas casas.

A personificaçăo da morte e da gripe possibilita um entendimento de que há uma força superior à humana circulando pela capital paranaense, concatenando, por exemplo, com a capa do livro que possui um céu absolutamente obscuro: entre caveiras, uma tinta negra cobre o espaço. Entre a realidade histórica explicada cientificamente e a inquietaçâo de náo se justificar empiricamente a presença macabra da morte, a obra escolhe ambas as possibilidades. Antes da segunda apariçăo da imagem do homem no texto, alguns outros indícios de sua presença-ausência se manifestam de maneira intermidiática. A notícia de primeira página no Diário da Tarde sobre "A Influenza" está em branco.

A notícia năo é noticiada. O título basta. Os leitores sabem da presença da gripe na cidade ao passo que, ironicamente, fica evidente uma tentativa das autoridades de censurar o acesso à informaçăo em um tempo em que a mídia noticiava sem tantos 
interesses obscuros. Essa presença, ausente no texto, se torna ausência presente em dois poemas (ou seria um só?) que aparecem entre uma foto de uma rua da cidade absolutamente deserta:

\begin{tabular}{|c|c|}
\hline $\begin{array}{c}\text { Entro na casa } \\
\text { a porta sem chavear } \\
\text { alguém que saiu para voltar } \\
\text { e năo mais voltou } \\
\text { entrou para sair } \\
\text { e náo mais saiu }\end{array}$ & $\begin{array}{c}\text { Năo sei porque } \\
\text { entro entrei }\end{array}$ \\
& nesta casa onde nunca entrei \\
& Pássaro em água estranha \\
& Vagueio pela penumbra do corredor \\
& pela porta entreaberta vejo (XAVIER, 1998, p. 18) \\
\hline
\end{tabular}

O primeiro poema (primeira estrofe?) indica que alguém que saiu para buscar ajuda para um doente, dentro da casa, náo voltou mais. Teria esta pessoa fugido? Ou no meio de sua fuga encontrou a morte? Deparar-se com a morte ganha um colorido especial se pensarmos que o eu lírico de ambos os poemas é o homem que personifica a gripe e a morte, enfim a força inquietante sobre a qual é inevitável lutar. Tal perspectiva se torna pertinente no segundo poema (segunda estrofe?), pois o eu lírico adentra um espaço que năo conhecia e complementa a informaçăo do primeiro poema: a pessoa que ficou na casa morreu, pois encontrou esse ser lúgubre. No contexto de horror imposto à sociedade, a gripe e a morte visitavam essas pessoas com frequência, o que torna desnecessário algum tipo de controle sobre o que está acontecendo. A poesia, mesmo sem fabulaçấo ou com uma fabulaçâo conjecturada na sua relaçâo com a imagem, carrega um valor alegórico importante àquele contexto social: a morte e a gripe estavam presentes em todos os lugares, inclusive dentro das casas, mas nos jornais năo.

Assim, há uma possibilidade de se ler a história através da literatura, através do poema concatenado com a imagem, através do que as pessoas consideram estranho, inquietante e inexplicável. Na sequência dessa narrativa estilhaçada, mais especificamente no dia 24 de outubro, há uma informaçăo jornalística da qual năo sabemos a fonte, pois há dois jornais disputando o espaço da verdade na narrativa, indicando em caixa alta que "NÄO MORREU NINGUÉM" (XAVIER, 1998, p. 20) na cidade. Apesar de ser o começo do surto e oficialmente ninguém ter efetivamente morrido, năo há um relatório a respeito do referido mês na obra, a morte e a gripe já chegaram.

Se oficialmente a morte nâo chegou, o poeta "José da Gaita", com um nome paródico que lhe retira toda a seriedade da circunstância e da possibilidade de dizer a verdade, anuncia: "De manhâ abro as gazetas/ nenhuma nota - que bola!/ Limpo e relimpo as lunetas/ Nada, nada de hespanhola.../ A policia nos socorre/ Toda noticia degola/-Aqui de vez, ninguém morre,/ Foi p'ro xadrez, a hespanhola." (XAVIER, 1998, p. 25).

O poema, denominado "A HESPANHOLA", escrito em caixa alta, indica que nenhuma informaçáo é dada pela imprensa. Ao mesmo tempo, o mercado da morte se aproveita da situaçăo para lucrar. Abaixo do poema, temos a propaganda de "Bromil - cura todas as doenças do peito, pulmóes e garganta". Ainda que um salto na análise da narrativa seja necessário por conta da limitaçăo espacial, já é possível estabelecer algumas comparaçóes entre os fatos noticiados e as manifestaçóes individuais, que contrariam aquele espaço público de informaçâo.

No mês de novembro, muitas referências à Primeira Guerra, experiência 
violentíssima para a humanidade por ter inaugurado a chamada guerra de trincheiras, săo localizadas nas páginas $01,06,08,11,12,13,20,25,29$ e 30 . Há ainda de se considerar o indício de uma guerra se aproximando do Brasil: no dia 27, o jornal anunciou a eminência de uma guerra entre Chile e Peru, provável desdobramento da chamada Guerra do Pacífico. Todavia, o que realmente se noticiou ao longo do mês foi o problema da gripe. Ela possibilitou a abertura de boticários no final de semana, fechou os cinemas e as igrejas temporariamente, fez com que faltasse madeira para fazer caixăo, enfim, a guerra em Curitiba era outra. Se, de uma maneira geral as notícias sobre a guerra superavam seu período mais crítico, a gripe espanhola na cidade náo cedia.

Na entrada referente ao mês de novembro, as imagens têm uma variedade enorme de temas: placas de luto, imagens de tumbas, corpos chaguentos, propagandas de remédio com um espaço muito maior na página, fotos de pessoas falecidas, anúncio de emprego em funerária, fotos de cortejos fúnebres, esclarecimento de empresa funerária que náo possui funcionário para trabalhar por motivo de doença, e, entre outras imagens, duas fotos do homem-morte sem a lapela à vista.

A segunda apariçâo dessa figura alegórica ocorre no dia 19 de novembro. No alto da página, a imagem da lapela vem acompanhada com os seguintes dizeres, também em caixa alta: "os óbitos de hontem" (XAVIER, 1998, p. 56). A seguir, a mensagem de que năo houve nem diminuiçăo, nem aumento. E na parte baixa da página, um poema com uma mensagem enigmática: "Ela geme baixinho, năo mais de febre/ agora de gôzo?/ Gózo e no auge do gôzo tento/ abraçar todo seu corpo que se/ me escapa e tenho nas mâos/ como um pássaro peixe" (XAVIER, 1998, p. 56). Se trabalharmos com o fato de que o eu lírico do poema é o homem-morte, subentende-se, neste poema e em outros textos do livro, que ele se aproveita, também, das ruas vazias para invadir casas e, possivelmente, estuprar mulheres que estâo sozinhas e doentes.

Entâo, o horror da populaçấo feminina se amplia diante do fenômeno (des)conhecido que assola a cidade. Enquanto isso, o itinerário de horror na vida cotidiana se amplia: a guerra está praticamente acabada, mas no dia seguinte, 20 de novembro, o livro noticia na mesma página que "A EPIDEMIA SO DECLINA PARA A SCIENCIA OFICIAL" (XAVIER, 1998, p. 57), enquanto que entremeada por outras notícias como uma greve que estoura na capital e será controlada pelo governo, ou a chegada das tropas americanas no Rio Reno, a página se encerra com a notícia de que "EM 13 OBITTOS, 10 SĂO DE CREANÇAS!" (XAVIER, 1998, p. 57). Diante de tantas notícias catastróficas, a experiência da modernidade năo pode ser racional. O cenário é de desolaçăo diante de uma cidade-fantasma. A ciência, percebida como panaceia da modernidade para muitos segmentos, mostra-se impotente, ineficaz.

Findo o ciclo da gripe, ou năo, no dia 30 de novembro temos a última apariçăo da figura do homem que fragmenta o livro e se impóe como um mistério insolúvel, tal qual a morte, a gripe, um estuprador, um poeta, o homem moderno. Na parte superior da página, quando tudo parece retomar o caminho da normalidade, surge a notícia de que o "KAYSER ESTÁ COM HESPANHOLA". Diante da ruína e do sinistro, o homem que liderava o outro lado da guerra pode morrer, ironicamente, de gripe espanhola. Seguindo a ela, a nota de que o tráfego de bondes normalizaria no dia seguinte. $O$ mundo se reorganiza, a paz reina, mas o homem e seu olhar indecifrável ali permanecem. Testando o equilíbrio do mundo, o tom lírico do poema escamoteia a violência do ato que encobre: 
"Mas sempre terei diante de mim/ a visăo de eu abrindo a porta/ a casa vasia, seu corpo de loura plumagem/Sem me voltar, sem voltar/ diante de mim a cidade vazia, silenciosa/ nestes dias da grippe/ ninguém me viu nem me verá" (XAVIER, 1998, p. 66). Nele, aquele homem sinistro que iniciou o livro volta na figuraçăo da morte, da gripe, ou um estuprador em potencial, entre outras histórias paralelas que se constroem nesse livro múltiplo.

Em dezembro, finalmente, outras atmosferas lúgubres săo construídas pelas notícias e pela narrativa. Há outros horrores a serem afirmados, negados, renegados e reafirmados; há a presença da morte, combatida e esquecida; há outra história a ser contada, sem inflexăo, sem reflexăo, tese, síntese e anti-síntese; e a perspectiva adotada para aquele homem alegórico, para qualquer homem que pertença à modernidade năo é só o da experiência do terrífico e do terror, afinal ele faz parte dessa modernidade, apensar de ser diferente dela e às vezes negá-la.

Neste sentido, a epígrafe de Marquês de Sade escolhida pelo autor completa o seu sentido:

Vê-se um sepulcro cheio de cadáveres, sobre os quais se podem observar todos os diferentes estados da dissoluçăo, desde o instante da morte até a destruiçăo total do indivíduo. Esta macabra execuçăo é de cera, colorida com tanta naturalidade que a natureza náo poderia ser, nem mais expressiva, nem mais verdadeira. (XAVIER, 1998, p. 9).

O homem e toda a sua humanidade foram aniquilados pelas forças da história que, em alguns momentos, nos parece inexplicável, intangível, insólita ou fantástica.

\section{CONSIDERAÇÕES FINAIS}

O nome de Valêncio Xavier nâo está comumente associado ao romance histórico no Brasil. Provavelmente nem houve aqui a intençáo deliberada de fazer um romance histórico, mas seu autor escreveu, malgré lui-même, uma ficçăo histórica. Nâo um exemplar obediente aos preceitos clássicos do gênero e sim uma desmontagem dele. Valendo-se, a todo o momento, dos registros do passado, sejam eles os da gripe espanhola ou da primeira guerra mundial, o livro privilegia o mistério insondável que escapa ao olhar da câmera ou ao cronista histórico; o fato, intraduzível por imagens ou palavras, que se oculta nos intratextos, sugerindo ao leitor a insuficiência de uma narrativa que o apazigue.

Assim como no Novo romance histórico, ou, ainda se quisermos, na metaficçāo historiográfica ${ }^{3}$, năo há verdades a revelar, pois só acedemos aos relatos do passado, aos seus vestígios. Toda narrativa histórica será uma construçâo, mais ou menos interessada, mas nunca imparcial. Novo romance histórico ou metaficçăo historiográfica desnudam o que calaram as histórias oficiais, as outras vozes, o que ficou de fora do inventário civilizacional.

3 Termo sugerido por Linda Hutcheon para denominar uma produçâo contemporânea altamente reflexiva que se vale de temáticas históricas. (HUTCHEON, 1991). 
É por meio de uma memória, social em grande medida, que se reativa esses conhecimentos, como acontece na recorrência aos depoimentos. A temática histórica parece nascer dessa forte impregnaçăo memorialística, dominante na arte de Valêncio Xavier e evidente na condiçăo do colecionador; colecionador de imagens, de narrativas, enfim, de um farto arquivo do passado.

Em meio a esses arquivos, desponta a cidade de Curitiba, enquanto tópico de tais figuraçōes: "A dimensăo memorialista das narrativas literárias e fílmicas de Valêncio Xavier é uma tônica bastante notável dessas memórias, Curitiba e Poe parecem ser centrais." (VITORIANO, 2017, p. 119). O mez da grippe, ao tecer um panorama da Curitiba da época, evoca, guardadas as devidas proporçôes, as Passagens, de Walter Benjamin, apontando para os estilhaços da percepçăo que se tinha da Paris no século XIX.

Também Edgar Allan Poe nâo deve ser subestimado nessa equaçâo, como lembra Vitoriano. O filme de 1983, que relê o emblemático poema do autor inglês, O corvo, testemunha o fascínio do escritor curitibano por adoçâo pelas tramas que se insinuam no tecido urbano, pelas faces relegadas no processo histórico, pelos dramas vividos por seus atores. Expressâo que ganha as cores do lúgubre, do macabro, favorecendo a criaçăo de uma atmosfera sinistra.

Ao contemplar a fatia esquecida, os gestos e os desejos que se perdem no burburinho da modernidade, a ficçăo de Valêncio Xavier torna-se também histórica, ou talvez histórico-fantástica, porque atualiza os sentidos do fato histórico no tempo em que escreve na mesma proporçăo em que dá voz aos verdadeiros personagens da história, homens assustados que, diante de fenômenos inquietantes, experienciam uma história tăo-somente sinistra, nefasta, lúgubre, fantástica.

Ao fazê-lo, diante dos ecos da barbárie, seja no distante solo europeu com os estertores da Primeira Guerra, seja na cidade de Curitiba, avassalada e rendida aos horrores da gripe espanhola, só encontra meios de expressâo pela via do insólito, pois, ousando repetir as palavras de Ronaldo Lima Lins: “É o caso em que o fantástico, resposta literária ao mito da Razăo, passa pelo absurdo e veste, enfim, a máscara da horrível alma do outro mundo da vida moderna, que é a coisa. (LINS, 1990, p. 44).

\section{REFERÊNCIAS}

BERMAN, Marshall. Tudo que é sólido desmancha no ar: a aventura da modernidade. Trad. Carlos Felipe Moisés. São Paulo: Companhia das Letras, 1986.

CESERANI, Remo. O fantástico. Trad. Nilton Cezar Tripadalli. Curitiba: Ed. UFPR, 2006.

HUTCHEON, Linda. Poética do pós-modernismo: história, teoria, ficçâo, Rio de Janeiro, Imago, 1991.

KUBOTA, Marília. Entrevista com Valêncio Xavier. Disponível em: https://mariliakubota. wordpress.com/2008/12/08/o-fantastico-mundo-de-valencio-xavier-3/. Acesso em 16/03/2018. 
LINS, Ronaldo Lima. O fantástico: a modernidade exorcizada. Revista Tempo Brasileiro - Passagens da modernidade, Rio de Janeiro, n. 69, 1984, p. 40-51.

LUKÁCS, Gyorgy. O romance histórico. Săo Paulo: Boitempo, 2011.

MENTON, Seymour. La Nueva Novela Histórica de la América Latina, 1979-1992. México: Fondo de Cultura Económica, 1993.

ORTIZ, Renato. Cultura e modernidade: a França no século XIX. Săo Paulo: Brasiliense, 1998.

TODOROV, Tzvetan. Introduçāo à literatura fantástica. Săo Paulo: Perspectiva. 1975.

VITORIANO, Helciclever Barros da Silva. “O corvo” (1983) curitibano de Valêncio Xavier: uma leitura poético-documental. Policromias. Rio de Janeiro, n. 4, jul/dez 2017, p. 116-141.

WEINHARDT, Marilene. Uma leitura de La Nueva Novela Histórica de la América Latina, 1979-1992. In: VELLOSO, Luiz Roberto \& MOREIRA, Maria Eunice. (Orgs). Questōes de crítica e de historiografia literária. Porto Alegre: Nova Prova, 2006.

XAVIER, Valêncio. O mez da grippe e outros livros. Săo Paulo: Companhia das Letras, 1998.

Submetido em 21 de março de 2018

Aceito em 16 de julho de 2018 